\title{
The uncertainties of Claudian's De Raptu Proserpinae
}

This article explores uncertainty in Claudian's late Antique Latin epic, the De Raptu Proserpinae. It first focusses upon the areas of artistic provisionality, rhetorical inconsistency, and indeterminacy, and then compares and contrasts Claudian's political poetry. It suggests that the mythological De Raptu can be read as an acknowledgment of, and detached reflection upon, the uncertainties Claudian would have been familiar with as one involved in politics and as a client poet. 
The uncertainties of Claudian's De Raptu Proserpinae

Formisano (2018: 50) has recently raised the idea of instability in Claudian's late Antique Latin epic, the De Raptu Proserpinae, arguing for a sense of "epistemic instability" in the poem which is produced both by "form (the interrupted and unfinished form of the text) and content (the myth of Proserpina), read as an allegory". This article further explores instability in the De Raptu. After an introduction to background uncertainty in the period, the piece focuses on uncertainty in three areas: artistic provisionality, rhetorical inconsistency, and narrative indeterminacy. Next, comparisons and contrasts are made with Claudian's political poetry (as broadly conceived). Finally, the article suggests that, for at least a presumed key audience consisting of those at Honorius' court, the De Raptu can be read as an acknowledgment of, and detached reflection upon, the uncertainties involved in Claudian's poetic career and the political situation. In this, it rejects Mastrangelo's belief the "insider" Claudian is unable to offer external scrutiny. ${ }^{\mathrm{i}}$ Instead, it builds upon the trend in scholarship which sees the mythological De Raptu as reflecting on contemporary political issues, such as the tense relations between the Roman empire which was split between the brothers Honorius and Arcadius. ${ }^{\text {ii }}$

\section{i) Background uncertainty and its impact on Claudian's political poetry}

The De Raptu Proserpinae was written around the last years of the fourth century C. E., presumably after Claudian's first known Latin work in the West, the Panegyric for Olybrius and Probinus (delivered early in C. E. 395), and before the end of C. E. 404. ${ }^{\text {iii }}$ By this period, careful presentation of appearance, whether mediated through written or non-written means, such as ceremonies, was a necessary element for successful rule. Among the court productions artfully showcasing events, we may include many of Claudian's poems. ${ }^{\text {iv }}$ Claudian was a client-poet, a writer 
working at the behest of others, and as such he was subject to the vagaries of patronage. He composed the Panegyric for Olybrius and Probinus for the Anicii family in C. E. 395 shortly before Theodosius I's death. Then, from C. E. 396 until 404, Claudian wrote mainly for Stilicho, Honorius' magister utriusque militiae, and the emperor Honorius. During Claudian's time in the West, there is evidence of other patrons: Florentinus, the addressee of the second preface of the De Raptu, and a Hadrianus and an Aeternalis referenced in the Carmina Minora..$^{\mathrm{V}}$ The search to ensure a supply of patrons, an inherently precarious situation, might be thought the expected lot of a client-poet, but Claudian's engagement with politics and the ruling elite of the late fourth century can only have added to the uncertain feel of his situation. Instability was an issue for the Roman empire in the last part of the fourth century C. E. Its size rendered it hard to control, vulnerable to the actions of usurpers such as Argobast's puppet Eugenius who had been proclaimed Emperor of the West in C. E. 392 and subsequently defeated in the battle of Frigidus in C. E. 394. Moreover, in the latter years of Theodosius I's reign, the empire was under strain from external pressures in the form of barbarian incursions such as by the Huns who invaded the East in C. E. 395. In January C. E. 395 Theodosius died after a comparatively lengthy rule of some fifteen years in power. ${ }^{\mathrm{vi}}$ The subsequent division of the empire between his sons, Arcadius and Honorius, further deepened the feeling of instability. Figures such as Stilicho on the Western side and Rufinus and Eutropius on the Eastern jostled to fill the power vacuum opened up by the placing of these two youths on the throne. ${ }^{\text {vii }}$ Stilicho's positioning of himself as the guardian of not only Honorius but also the elder brother Arcadius gave rise to dissension. ${ }^{\text {vii }}$ The period of Stilicho's patronage would have seemed more stable in retrospect than at the time in light of the uncertainties surrounding the general's power base. There was no way of knowing that Stilicho's sway over Honorius, which lasted until C. E. 408, would have lasted as long as it did.

The responsive nature of Claudian's poetry to events can be shown in his first court commission, a panegyric on the third consulship of the Emperor Honorius in C. E. 396, which reacts 
to the change of rule necessitated by Theodosius' death. It is particularly notable for its attempt, in the speech attributed to the dying Theodosius I, to establish Stilicho as guardian of both Arcadius and Honorius: the existence of unhappiness with Stilicho's stance meant that Claudian needed to spin, to put a good slant on, the situation. ${ }^{\text {ix }}$ The power shifts caused by Theodosius' death were only the start. Claudian was writing in a world of rapidly changing alliances and enmities. Alaric and his Visigoths had fought with Theodosius I (and Stilicho) against Eugenius at Frigidus in C. E. 394 but the following year they rebelled against Honorius and Stilicho. ${ }^{x}$ In C. E. 398 Stilicho sent forces to deal with Gildo, the Comes et Magister utriusque militiae per Africam, who had transferred allegiance from West to East in C. E. 397. Gildo had previously fought under the Comes Theodosius against his half-brother Firmus following Firmus' uprising (C. E. 372-5). Even favourites were not immune from shifts in circumstances, as demonstrated by the fall from grace of Theodosius' former minister Rufinus, who became the target of Claudian's invective with the In Rufinum in C. E. 396-7.

Such a situation will have necessarily impacted upon Claudian's political poetry, the strategies of which were formed in response to fast-changing, often tumultuous, events and the political handling of these events. Claudian would often have had little time to prepare. So his De Bello Gildonico, delivered in Spring C. E. 398, was written to treat the revolt of Gildo which seems to have been unexpected. De Bello Gildonico 16 suggests Gildo was declared a public enemy in the winter of C. E. 397. And, whatever the timescale of events in the months leading up to this, there appear to have been scant sign of unrest in Africa in C. E. 395 and 396 (Wijnendaele 2017: 390). Writing for Stilicho and the imperial house clearly required the ability to adapt, to incorporate new material, and to change course. Thus the narrative of De Bello Gildonico remains stuck with the ships at 1.526 after the deliverance of Book 1 in C. E. 398. For a second book would have necessitated a key focus on Gildo's brother, Mascezel, who had headed the forces against Gildo but who had since fallen out of favour. ${ }^{\mathrm{xi}}$ Claudian does, however, return to the war against Gildo in Book 1 of his panegyric on the consulship of Stilicho (C. E. 400). And here we see changes in treatment which can be explained by 
political changes: in the De Bello Gildonico, Claudian does write in ways that support his patron, who was in a politically weak position, but Stilicho's strengthened position by the time of his composition of De consulatu Stilichonis allows for more direct praise. ${ }^{\mathrm{xii}}$ The changes in situation could even impact the format of Claudian's poetry. The first book of In Eutropium, which employs an invective structure suitable for its focus on an individual, Eutropius, was delivered in Spring C. E. 399. ${ }^{\text {xiii }}$ In the following months Claudian composed a seemingly unplanned sequel, which was delivered in September 399. ${ }^{\text {xiv }}$ The epic nature of the second book allows for more general coverage, such as an anti-Eastern and anti-Constantinopolitan slant. ${ }^{\mathrm{xv}}$ The fall of Eutropius in the August is one factor which will have encouraged the new pursuit of epic scope and treatment and the broader focus this permitted. ${ }^{\mathrm{xvi}}$

\section{ii) Uncertainty through artistic provisionality}

Having established the unstable contemporary situation and its impact on Claudian's political poetry, it is time to turn to the De Raptu. On the face of it, this mythological work seems very different to the occasional poems which were tied to socio-political events. However, on some levels there is considerable overlap, as we can see if we examine the poems' interest in rhetoric. The $D e$ Raptu draws attention to the ways in which words may persuade and can drive action, as shown by the first one hundred and sixteen lines of the narrative proper. Dis' preparations for war (DRP 1.3247) are defused by the speech of Lachesis (1.55-67). In turn, this speech leads onto Dis' "angry words" (DRP 1.76 fervida dicta) demanding that Jupiter should grant him a wife (1.93-116), a request which is destined to be granted. For Jupiter's power, gained after the overthrow of his father Saturn, appears to be not so secure that he does not need to placate his brother, the "third heir of Saturn" (DRP 2.167-8 tertius heres / Saturni) who is threatening to loosen Saturn's chains (1.114). Whether in his panegyrics or his political, non-panegyrical poems, words are the means by which Claudian 
uses to propagate his clients' positions. At a key level the success of the poems depended upon conveying what message or messages they were intended to convey. For Claudian's panegyrics, which take the form of speeches, the audience involved subsequent readers as well as those listening at Milan, Ravenna, or Rome, and different cohorts within these groups. Claudian carefully crafted his material with audiences in mind. Thus Claudian's panegyric for the consulship of Probinus and Olybrius came at the behest of the Anicii family. And with its flattery of the consuls themselves and their literary-minded gens, it is clearly tailored towards the Anicii as repicients. ${ }^{x v i i}$ However, it also has the wider audience of the Roman senate strategically in mind. ${ }^{\text {xviii }}$ Characters in the De Raptu also adapt their material in view of their audience as shown by the way Dis hastens to set out the flowerpicking potential of Proserpina's new home at $D R P 2.286-8$ in response to her allusions to the flowers that had tempted her (2.265).

The focus of this article is to bring the De Raptu and the political poems together through the lens of uncertainty. That an air of uncertainty attends the De Raptu is evident through its recurring theme of artistic provisionality. Poetic provisionality is clear in the way the poem's ending at $D R P$ 3.448 leaves unfulfilled the plot expectations of a description of Ceres' travels and bestowal of corn raised by the proem ( $p r .1 .28-31)$. The breaking off of Ceres' journey is particularly marked since it had both been advertised at De Raptu 3.315-27 and started at 3.406 (incohat). As Hinds has shown, the ending of the poem is carefully constructed: the narrative, which had been preceded by a preface paralleling a poet and sea-farer ( $D R P$ pr. 1.1-12), finishes abruptly at 3.447-8 with a reference to the notorious marine-hazard Scylla, as if it were ship-wrecked: "with the dogs drawn back, some were silent in amazement and some, not yet terrified, barked" (canibus ... reductis / pars stupefacta silet, pars nondum exterrita latrat. $)^{\mathrm{xix}}$ A more attractive possibility than the idea it was a careless termination resulting from circumstances outside of the text's control (such as the death of the poet or the disgrace of his dedicatee Florentinus) is that Claudian deliberately stopped his work at 3.448, and allowed the circulation of a fragmentary work, whether or not with the intention of restarting. ${ }^{\mathrm{xx}}$ 
An air of poetic provisionality is also created through the theme of insecurity of patronage. This theme is implicit in the staging of Claudian's resumption of his abandoned epic through Florentinus' patronage in lines 49-52 of the second preface: "But you, Florentinus, are a second Hercules to me: you stir the plectrum of my lyre and shake the caves of the Muses sluggish from their long sleep and lead the gentle bands in a circle" (sed tu Tirynthius alter, / Florentine, mihi: tu mea plectra moves / antraque Musarum longo torpentia somno / excutis et placidos ducis in orbe choros). ${ }^{\mathrm{xxi}}$ The celebration of Florentinus' patronage in the preface of Book 2 comes with an acknowledgement that previous patronage has ceased.

The preface of Book 2 further explores the vulnerability of the artist through the Ur-poet Orpheus with whom Claudian aligns himself. ${ }^{x i i}$ The music of this "Thracian bard" (Thracius ... vates, DRP 2 pr. 49), had provided "solace" (DRP 2.pr. 3 solacia) to the nymphs and exerted control over nature (2. pr. 5-6), but then it had been halted through circumstances, which we must surely understand to be the loss of Eurydice. ${ }^{\text {xiii }}$ In pointed contrast to the Vergilian Orpheus of Georgics 4, who continues his song, thereby "soothing tigers" (Verg. G. 4.511 mulcentem tigris), after his failure to restore Eurydice, the Claudianic Orpheus falls silent so that savagery returns to the wild beasts (DRP 2 pr. 5). ${ }^{\text {xiv }}$ Moreover, even though the preface relates how Orpheus' music is restarted by the circumstances of Hercules' liberation of Thrace (DRP 2. pr. 9-16), there are intimations of its future and final cessation: as the passage reminds us through evocation of the death-scene of Ovid's “Thracian bard”, Orpheus' song can only be temporary. ${ }^{\mathrm{xxv}}$

Furthermore, we are nudged to link circumstances within the poem to external circumstances of its composition. The portrayal of Proserpina weaving the origins of the universe in Book 1 creates the same sense of artistic provisionality found in the depiction of the poem's own creation. ${ }^{\text {xxvi }}$ Venus arrives "suddenly" (DRP 3.207 subito), alongside Pallas and Diana and so the "task" (1.271 laborem) of the tapestry is abandoned whilst "unfinished" (1.271 inperfectum) (DRP 1.271-72). ${ }^{\text {xxvii }}$ The artist figure Proserpina lacks ultimate control over her work, as is highlighted by the contrasting structural 
finish provided to the passage by the master-poet, with its careful positioning of the word "middle" (DRP 1.259 mediam) mid-line in the middle of the ecphrasis $(1.248-70){ }^{\mathrm{xxviii}}$ The tapestry never becomes the finished product which is given to Ceres but stands as an "ineffectual present" (DRP 1.247 inrita ... munera). The "interrupted craftsmanship" (DRP 3.156 interceptas ... artes) is resumed in a way by the weaving of the spider (3.157-8) who becomes a substitute artist figure. Yet, crucially, the work remains still incomplete: the imperfect tense of supplebat (DRP 3.158 "it was completing") depicts the spider's efforts as an ongoing process. Although no more is heard of the spider, the subsequent description of Ceres kissing the loom and stifling her complaints among the threads (DRP 3.159-160) raises questions about its completion of its task. What is more, the fact that the second preface follows on from the description of interrupted weaving encourages us to make a connection between the poem and the tapestry, especially since our attention is clearly drawn to a delay. For the preface draws a parallel between Claudian, who had halted the poem only to take it up again after a "long sleep" (pr. 2.51 longo ... somno), and Orpheus, who had ceased from his song and lyre-playing "for a long time" (2 pr. 2 diu) only to restart, like the Ovidian Orpheus who returns to lyre and song (Met. 10.89, 145-7) after a three year hiatus caused by grief for Eurydice (Met. 10.78-9). As Hinds (2016, 274, n. 25) has suggested, a link is created between the evocation of lapsed time in the tapestry's description and the time lag in poetic composition flaunted at line 51 of Book 2's preface. ${ }^{\text {xxix }}$ Thus the reader is encouraged to connect the air of uncertainty surrounding the poem's composition with uncertainty surrounding the production of internal artwork.

iii) Uncertainty through rhetorical inconsistency.

Uncertainty is also generated though rhetorical inconsistency. Take Electra's artfully contrived account of events for the bereft Ceres at De Raptu 3.196-259. The presentation of the nurse's shame and fear in the preceding lines (DRP 3.192-5) primes us to be on the look out for self-exculpation 
and, indeed, her words reveal that she is on the rhetorical defence. So Electra, who is said to be considered Proserpina's "second mother" (DRP 3.176 proxima mater), tailors her narrative against Ceres' charge that she has failed to "watch over the offspring of others" (3.191-2 aliena tueri / pignora). As Gruzelier observes, Electra uses the phrase "our naïve one" (DRP 3.215 nostra rudis) of Proserpina to "link mother and nurse in their relationship to their charge." ${ }^{x x}$ And, when Ceres reproachfully inquires about Proserpina's companions, such as the "thousand attendants" (3.189 mille ministrae), Electra emphasizes that Proserpina was "in the protection" (DRP 3.230 praesidio) of actual family, "sisters" (3.229 sororum). Other indications in the text suggest the nurse is spinning events. Thus, for instance, the positive portrayal of Proserpina's domestic confinement at De Raptu 3.202-6, starting with the nurse's claim that the house "was flourishing" (3.202 florebat), belies the ease with which Proserpina was persuaded to leave the house $(2.4-6):{ }^{x x i}$ clearly the flourishing house could not compete with actual flowers, just as playing in the meadow (2.77 ludere) proved a greater lure than the household's "cautious games" (3.206 cauti ... ludi). ${ }^{\mathrm{xxxii}}$ Furthermore, scrutiny of the speech's style suggests careful crafting: so Electra draws attention away from her own role in the actual abduction by relating departure to the meadows through the use of the impersonal verb of motion, itur (DRP 3.231). ${ }^{\mathrm{xxxiii}}$ With the exception of vidi ("I saw") at De Raptu 3.241 (used to convey her eye-witness account of the devastation), the first person is not deployed until 3.245 , and then it is the first person plural which is used to ally herself with others concerned for Proserpina's fate. ${ }^{\text {xxiv }}$

Suspicions that Electra is drawing on all her rhetorical reserves to present the best possible case encourages us to scrutinize her record of events (DRP 3.196-259) against the third-person narrative of the abduction and its lead-up $(1.270-88 ; 2.1-307) .{ }^{\mathrm{xxv}}$ Inconsistencies become apparent and these contribute to a sense of uncertainty. We realize that it is only now that we hear of Electra's attempt to persuade Proserpina to stay (DRP 3.228-9). Another discrepancy is that Diana and Pallas are painted as co-conspirators at De Raptu 3.198-9 whereas the narrative had portrayed them as 
rallying to Proserpina's aid at 2.205-228. We cannot know if Electra is lying. Perhaps the nurse's pleas were glossed over in the narrative gap between the entrance of the goddesses (DRP 1.270-1) and Proserpina's departure for the meadows (2.4), instead of being made up to excuse herself from blame. Perhaps, rather than alleging collusion in order to lessen her responsibility, Electra assumed the complicity of Diana and Pallas after darkness hid their actions from view. However, at the least we may suspect that the inclusion of this material in her speech is designed to exonerate herself. ${ }^{\text {xxvi }}$ Inconsistency is an element of the Classical epic tradition, as O'Hara (2007) has well demonstrated. So, for instance, Ovid Metamorphoses 1 features the example of Jupiter's address to the divine council containing the god's rhetorically crafted justifications of his plan to destroy humankind and his past treatment of the apparent threat Lycaon. ${ }^{\text {xxxvii }}$ It is clear that Jupiter is trying to put his actions in the best light, as shown by his careful attribution of agency. ${ }^{\text {xxxviii }}$ The inconsistency between the third person narrative and Jupiter's speech exposes the unreliability of the speaker. ${ }^{\text {xxix }}$ Another example of inconsistency involves Jupiter's actions and presentation of the situation in Statius' Thebaid. Thebaid 1.197-213 presents a divine council followed by Jupiter's speech in which he explains how he is going to punish Argos and Thebes through war (1.214-27). Yet, prior to this we have seen Oedipus praying to the infernal powers for vengeance against his sons Polynices and Eteocles (Theb. 1.56-87), since Jupiter had ignored his situation (1.79-80), and Tisiphone's consequent stirring up of strife between the brothers. The confusion over who is driving events can be linked to the power of the underworld and the Statian ruler's lack of absolute control: it would appear that Jupiter is playing catch-up, aiming to assert his authority over a war that has already started. ${ }^{\mathrm{xl}}$ Moreover, there is further inconsistency in that it initially appears that Jupiter is spontaneously arranging war in response to Oedipus' prayer whereas at Thebaid 3.241-3 and 7.197-8 he asserts that the Argive-Theban war was fated. Setting Jupiter's assertions in their context helps explain these references to fate. Thebaid 3.241-3 is part of Jupiter's speech to Mars and the other gods (3.229-52) and follows Jupiter's acknowledgment of potential opposition to his plan (3.240-1), something which 
has previously been made clear by Juno's unhappy reaction to his initial divine council (1.250-82). He quashes dissent by threatening he will upend Thebes over Argos or cause a flood, even if it would endanger Juno (3.244-52), but also uses reference to the authorization of fate as a way to bolster his position. The second instance of reference to the Fates comes after Bacchus' protest against the planned destruction of Thebes (Theb. 7.155-192) and within Jupiter's attempt to reassure the god (7.195-221). Again the reference to Fate can at least be partly be traced to diplomatic motives as Jupiter works hard to deny any personal interest. Whilst we may not wish to eliminate the role of fate in the war, we may nevertheless appreciate the politics of Jupiter's references to it. ${ }^{\text {xli }}$

It is not surprising that a poet so steeped in the Classical epic tradition as Claudian should himself exploit inconsistency. What is notable is that in the 1108 lines of the De Raptu's extant mythological narrative we encounter three cases of inconsistency — and that all of these are bound up with rhetorical need. Prior to the nurse's address, the reader encounters inconsistency in Dis' speeches to Jupiter and Proserpina. When presenting his marital case after the abduction at De Raptu 2.277306, Dis attempts to convince Proserpina that Hades is better than the upperworld. ${ }^{\text {xlii }}$ The god claims that the underworld has "other stars" (DRP 2.282-3 altera ... / sidera) and a "purer light" (2.283-4 lumenque ... / purius). However, Dis has previously complained to Jupiter that Hades is "free of the pleasant light" (DRP 1.99 grati ... luminis expers) and contrasted his lot with Jupiter's, who experiences the Bear constellation and Zodiac (1.101-2). ${ }^{\text {xliii }}$ On one level, there is no dissonance: Dis refers to Elysium in his words to Proserpina (DRP 2.284) and a chthonic Hesperus does indeed appear in the wedding scene at 2.361. ${ }^{\text {xliv }}$ Nevertheless, our attention is drawn to the discrepancy between his presentations which is linked to the change of addressee and events and which is rhetorically motivated. Dis tailors his words to circumstances and his audience as part of his persuasive strategy. The god has a vested interest in portraying Hades negatively in the first speech, to strengthen his case for the need for marriage, and positively in the second, to woo over Proserpina 
whom he has carried off. Dis glosses over the less appealing parts of his dominion and counters Proserpina's fear, articulated at De Raptu 2.261-3, that she is losing the light.

The other example of inconsistency, which has received particular critical attention, involves Jupiter's motivation. ${ }^{\text {xlv }}$ This case has even been given as evidence that Claudian "slightly altered his outlook as he composed". xlvi The narrative shows us Jupiter responding to Dis' threats of cosmic disruption (DRP 1.113-16): the king of the gods comes to the resolution that harmony must be preserved through provision of a wife: audierat mandata pater secumque uolutat / diuersos ducens animos, quae tale sequatur / coniugium ... / certa requirenti tandem sententia sedit (DRP 1.118-21, "The father had heard the commands and was considering it by himself. He was pondering different options, considering who would seek such a marriage... At last a fixed opinion came to him as he looked for a solution"). However, during his speech to Venus at De Raptu 1.216-28, Jupiter informs the goddess that the marriage was long fated (1.217-19) and then, in the divine council scene of Book 3, Jupiter claims that the abduction is part of a larger providential design, stimulated by Nature's complaints, which will result in the bestowal of agricultural knowledge on mankind (DRP 3.45-54). Whilst the Fates' urging of Dis to ask for a wife at De Raptu 1.67 could be read as validating Jupiter's words to the gods (cf. $D R P 2.6 ; 2.7$ ), there nonetheless remains a sense of inconsistency. ${ }^{\text {xlvii }}$ The spontaneity of Jupiter's decision to give Dis a wife, specifically Proserpina, is in tension with his later claim of the involvement of fate and Nature. When resolving how to appease Dis, Jupiter is acting within the course of fate. And, indeed, he later becomes an important player in it: the concluding line of his speech at De Raptu 3.65 to the gods plays on the ambiguity of fata as "spoken things" and "fates" to underscore how his words are shaping destiny. ${ }^{\text {xlviii }}$ Yet looking back at the decision of De Raptu 1.118-21 from the view of the later narrative, it would seem Jupiter is initially unaware either of this course of fate or its details and relevance at this juncture.

We need not, however, take the discrepancy in motivation as a narrative flaw but rather we could read it as acting to signpost the unreliability and skill of the speaker. When he needs to persuade 
Venus to help him, Jupiter spins the situation as best as he is able. He crafts his speech to include the impersonal phrasing of Proserpina ... / ... decreta dari (DRP 1.217-18 "Proserpina was decreed to be given") and the attribution of agency to other figures like the Fates and Themis (1.218-19). However Jupiter's understanding of the course of fate developed, it is politic for him to emphasize the role of fate when attempting to co-opt Venus. Jupiter presents the abduction as ordained long ago and by other parties, rather than as a personal decision, which gives his argument persuasive heft. He goes on to flatter the goddess' sense of power (DRP 1.223-4) and cultivates her sense of agency. When he asks "why should the lowest kingdom be at rest?" (1.224 cur ultima regna quiescunt?), he carefully omits to mention that Dis has asked for wife and children for "such inactivity must not be tolerated" (DRP 1.111 non adeo toleranda quies). ${ }^{\mathrm{xlix}}$ There is no hint that Jupiter might be responding personally to a situation which threatens his power.

Later on, Jupiter must persuade another audience, justifying the rape retrospectively to the divine assembly. His depiction of events in the council speech of De Raptu 3.19-65 can similarly be analysed in terms of how Jupiter might best assert his will. How far Jupiter is fabricating or manipulating the account of Nature's intervention must remain uncertain. However, the inconsistency with previous accounts encourages us to scrutinize the rhetorical angle of the argument. At De Raptu 3.47, Jupiter asserts "I have decided" (statui). Then, some four lines later, he claims "it is decreed" (DRP 3.51 decretum). In order to bring out his own role in doing the bidding of Nature for the greater good, Jupiter employs the personal voice. Yet he also uses the impersonal voice, which carefully leaves open the question of who was responsible for the decision but suggests the involvement of others. For all the appearance of altruistic benevolence (Jupiter emphasizes he is not acting on his own behalf), the king of the gods is acting as a dictator in this scene. Authoritative weight is added by presenting events as decided by some other party.

Uncertainty is created by the narrative's presentation of competing accounts with no resolution given by the extant text. The details in the case of the nurse's speech may be of minor significance, 
and can be explained away. Inconsistency in Dis' two presentations of the underworld can be attributed to rhetorical reasons, at least before the vision of the ghostly Proserpina who appears like one of the tortured in Tartarus. ${ }^{1}$ It is not as easy to dismiss the inconsistency concerning Jupiter's motivation. In his speech, Jupiter gives the impression that Ceres' wanderings and bestowal of grain (DRP 3.50-4) are the planned result of his decision, outlined at 3.47, to stop man's acorn diet (3.48 ideo, "for that reason"). However, we only have his word for it. At the start of the poem, the move from acorns to grain had been portrayed in neutral terms as a consequence of Ceres' wanderings (DRP 1.30 "whence", unde), with no hint that this was part of a grand plan. We are encouraged to ponder how far Jupiter has been acting to secure a providential outcome for mankind versus how far he has been working to protect his position. The suggestion that he requires careful rhetoric to secure his desires does not breed confidence that this ruler is in full control.

\section{iv) Uncertainty through narrative indeterminacy}

We have so far seen the generation of uncertainty through the presentation of artistic production and inconsistencies in the narrative. A third way in which a sense of uncertainty is produced is through indeterminacy, here defined using Cosgrove's formulation as "the recurring interpretative situation in which I perceive there to be two or more reasonable but competing interpretations, that is, two or more mutually exclusive interpretations that are plausible/defensible on the basis of a rigorous application of the same methods or what I judge to be appropriate competing methods". In the council of Book 3 Jupiter has an agenda: he is aiming to convince his audience of the rightness of his actions and prevent any intervention from the other gods. The ruler's warning that any deity who tells Ceres about the abduction "will feel the blow of his thunderbolt" (DRP 3.60-1 sentiet ictum / fulminis) acts to cast such informers not only as opponents but as quasi-gigantomachic figures, for Jupiter had used thunderbolts in the divine battle against the giants. Dis, by contrast, is 
presented as bound more tightly to the Olympian group by his new status as "son-in-law" (DRP 3.63 genero). From Ceres' perspective, however, the abductor's role is that of a giant, a hostile aggressor towards the gods of Olympus, as we can see from De Raptu 3.181-8, in which Ceres equates the taking of Proserpina with the attack of the giants.

Our view of the abduction is also complicated by the narratorial perspective. On one level, the portrayal of events shows support for the side of Proserpina and her allies. See, for instance, the way Dis is set up as a giant figure by the description of his journey over the giant Enceladus, whose back is sulphurous from Jupiter's thunderbolts, a move which creates sympathy for Proserpina as the target of his abduction. ${ }^{\text {lii }}$ Admittedly, a shift does occur in how the poem maps protagonists against mythological figures. And the turning point for this is the explicit Olympian backing of the abduction demonstrated when, at De Raptu 2.228-31, Jupiter hurls a thunderbolt, "revealing himself to be the father-in-law" (2.230 confessus socerum), in order to deter Pallas and Diana from aiding Proserpina. Whilst the thunderbolt is benign, Jupiter's action coerces the goddesses by suggesting their opposition to him is acting out the opposition of giants. ${ }^{\text {liii }}$ And the narrative encourages us to read the scene in a gigantomachic light. At De Raptu 2.225, Pallas intimidates Dis' horses with the Gorgon image she bears (and had already unveiled in readiness at 2.205): the gesture reminds us of her involvement in the gigantomachy. ${ }^{\text {liv }}$ The former giant-conqueror is now figured on one level as a giant. After this Ceres appears as giant-like in the way she takes trees from a grove decorated with the giant-spoils (DRP 3.335-85) and is said to be ready to attack Jupiter himself (3.359). ${ }^{\text {lv }}$ However, Jupiter's backing for Dis predates his hurling of the thunderbolt: at the point at which Dis is portrayed aggressively journeying towards Proserpina in giant-like fashion, he has the support of the king of the gods. Hence the narrative perspective does not simply tally with Jupiter's presentation of events but there are two conflicting viewpoints. The question is opened up as to who is the giant figure: the abductor or the supporter of the abductee? There are two "reasonable but competing interpretations" indicative of 
indeterminacy. In this part of the text we have two irreconcilable perspectives and due to the poem's unfinished nature they are destined never to be resolved by the plot.

Linked to this is the view of the union between Proserpina and Jupiter: is it a legitimate

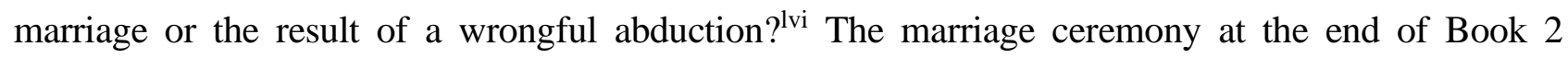
contributes to our uncertainty over how to see the union. The journey that ends with a quasi-Roman deductio as the "maiden" Proserpina "is led" as a bride "into the marriage-chamber" (DRP 2.362 ducitur in thalamum uirgo) starts with forcible seizure (2.264 seruitum Stygio ducor captiua tyranno, "I am led as a captive to serve the Stygian tyrant"). ${ }^{\text {lii }}$ It is clear this is no ordinary bridal procession, even allowing for the fact that Proserpina's residence in Sicily, "far from her father's stars" (DRP 3.214 patriis procul ... astris), means that she could not have started off from her father's house. Further strains appear if we regard the union from the perspective of contemporary marital law: authorization by the father is insufficient when the bride has not given her consent and Jupiter could even be said to facilitating an abductive marriage. ${ }^{\text {lviii }}$ The uncertainty is sustained by our last two glimpses of Proserpina which picks up the tension we have seen between the two competing presentations of the underworld in Dis' speeches: do we remember her as a blushing bride (DRP 2.325) or the unhappy ghost of Ceres' vision? ${ }^{\text {lix }}$

\section{v) Comparison and contrast with Claudian's political poems}

Having established three ways in which uncertainty is established in the De Raptu, we may now turn to the political poems for comparison. Claudian is not critical of any particular patron in the De Raptu, glossing over the reason why new support is required, but the poem does raise the issue of insecurity of patronage. This theme is not something that those works in the Claudianic corpus concerned with the aggrandisement of figures of authority lend themselves to, for the figures in those poems are associated with bringing positive assets like the Golden Age conditions of peace 
and unity about to be ushered in during the consulship of Olybrius and Probinus. ${ }^{\mathrm{lx}}$ In the De Raptu, there is not the same direct link between the dedicatee, Florentinus, and the world of the poem. Whilst the preface to Book 2 clearly lauds Florentinus as peace-bringing and a second Hercules, such praise is, at least on the surface, confined to the preface. ${ }^{1 x i}$ And, in comparison to the honorands of Claudian's panegyrics, Florentinus slips largely, although surely not wholly, from view. Although the creation of the poetic world is dependent upon Florentinus' support, the universe of the poem is a mythological universe far removed in time and space.

Since the universe of the De Raptu is distant, it may be populated with a somewhat questionable leader like Jupiter, a situation not possible in the political poems supporting Stilicho and the imperial house. In his poems for the powerful, Claudian is concerned to suggest a universe overseen by authority figures, notably Stilicho who provides the bedrock that allows the empire to withstand shocks and jolts, and whose actions enable concord.lxii The actions of Stilicho can even be presented as following the will of the gods: the In Rufinum presents Rufinus' punishment as due to

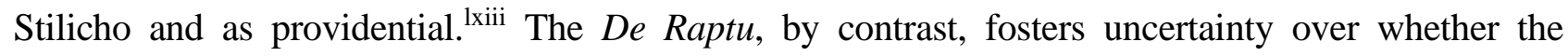
actions of Jupiter are done to protect his power base, to fulfil providence, or to achieve both of these aims.

There is also a difference in the transmission of message. Taken together, the political poems do reflect the uncertainty of the background period in some ways. For they were driven by rhetorical need which itself was motivated by historical factors. They contain examples of inconsistency which can be linked to the fast-moving and changeable historical situation, as shown in the way Mascezel's role in the war against Gildo is glossed over in Claudian's return to the war in Book 1 of his panegyric on the consulship of Stilicho. However, we may trace persistent policies, such as the need to support Stilicho's position, even if we remember inconsistencies. ${ }^{\text {xiv }}$ And within individual works we can find coherence: both books of In Eutropium promulgate a negative portrayal of Eutropius who threatened Stilicho's aim of having sway over Arcadius. From his perspective as a client-poet, Claudian's 
primary aim was to write poetry which would achieve its specific goals, to persuade, flatter, or damn as required. Anything which would obviously undercut this was avoided. There is not the same conflict of perspectives that we see produced by the narrative of the De Raptu: the enemy is clearly the enemy. Nor is there any undercutting by drawing readers' attention to the rhetorical crafting of the speeches or through narrative detail. In his speech at De Raptu 2.277-306, Dis creates his own epithalamic poetry. When he puts a gloss on dynastic marriage, we are encouraged to see this for what it is and ponder Proserpina's reaction. The creation of epithalamic material is the kind of job Claudian himself was responsible for and indeed, may already have done with the wedding poetry for Honorius and Maria, depending on when we date the De Raptu. ${ }^{\mathrm{lxv}}$ The expectation is that, on the primary level, the reader of that type of verse would be convinced by the positive portrayal of the marriage. There is no subsequent vision of a distraught Maria to complicate the reader's reactions. Electra presents events in a way that excuses herself and blackens others, just as Claudian excuses Stilicho and besmirches his enemies. However, the De Raptu also draws attention to potential inconsistencies between her speech and the third person narrative which appear to be a product of the nurse's rhetorical requirements. Such a strategy of undercutting would be counterproductive in the political poems. Whilst appreciation for Claudian's rhetorical skill may be roused by the political poems, we are not encouraged to perceive spin that would invalidate the message.

The De Raptu's thematization of composition as provisional, dependent for continuation on outside factors and liable to interruption, surely resonates with the circumstances in which Claudian, a client-poet at a time of volatile politics, was working. Yet this is not a picture we receive from the political poems. However uncertain the conditions in which he composed and backdrop against which he wrote, Claudian typically strove to give an impression of control in his political poems. Difficulties may be evoked but also the promise of order. There is ultimately a feeling of security due to the men in charge. Indeed, there is an extra sense of reassurance in those poems written to bolster Claudian's patron, Stilicho, for the figure who supports the writing and the empire is one and the same. The 
universe of the De Raptu stands in contrast, generating, with its suggestion of the insecurity of Jupiter's power base, a more unstable feel. The plot itself provokes uncertainty, and not only due to the fact that its flaunted lack of finish leaves readers unsure how matters would progress: uncertainty surrounds important details like the abduction's motivation, despite the fact that the king of the gods sends a clear message as to how he wishes events to be seen. Our attention is drawn towards Jupiter's rhetorical spinning of an action which, on one level, has stemmed from an immediate and, in the political conditions, necessary response to unforeseen events. The De Raptu does present a very different world view to the political poems. But what of its relation to the turbulent, unpredictable events that were happening at the time? What of its relation to the responses of the men in charge which must have been more ad hoc than they cared to admit and not the way presented by poets such as Claudian? With the distancing permissible through mythological content, the De Raptu can be seen as a way of conjuring and reflecting upon an alternative way of seeing matters, a way a court audience

would arguably have found more accurate than imperial presentations. This angle thus provides another instance of the fruitfulness of setting Claudian's poem against its contemporary political backdrop.

\section{Bibliography}

Balsley, K. 2011. "Truthseeking and Truthmaking in Ovid's Metamorphoses 1.163-245", Law and Literature 23:1, 48-70

Birt, T. 1892. Claudii Claudiani Carmina, Auct. Ant. X. Berolini: Apud Weidmannos. Bureau, B. 2009. "Figures de poètes chez Claudien", in Manifestes littéraires dans la latinité tardive: Poétique et rhétorique, edd. P. Galland-Hallyn and V. Zarini, 51-70. Collection des études augustiniennes. Série Antiquité ; 188: Paris, Institut d'Études Augustiniennes. Cameron, A. 1970. Claudian: Poetry and propaganda at the court of Honorius. Oxford: Clarendon Press. 
Cameron, A. 2011. The Last Pagans of Rome. Oxford: Oxford University Press.

Charlet, J.-L. 1991. ed. Claudien: Oeuvres: Tome 1. Le Rapt de Proserpine. Paris: Les Belles Lettres.

Cosgrove, C. H. 2004. The Meanings We Choose: Hermeneutical Ethics, Indeterminacy and the Conflict of Interpretations. London: T \& T Clark International.

Dominik, W. J. 1994. The mythic voice of Statius : power and politics in the Thebaid. Mnemosyne, Suppl. 136. Leiden: Brill.

Fauth, W. 1988. "Concussio Terrae. Das Thema der seismischen Erschütterung und der vulkanischen Eruption in Claudians De Raptu Proserpinae", Antike und Abendland 34: 63-78.

Feeney, D. C. 1991. The Gods in Epic: Poets and Critics of the Classical Tradition. Oxford:

Clarendon Press.

Feldherr, A. 2002. "Metamorphosis in the Metamorphoses" in The Cambridge Companion to Ovid, ed. P. Hardie, 169-72. Cambridge: Cambridge University Press.

Felgentreu, F. 1999. Claudians Praefationes. Bedingungen, Beschreibungen und Wirkungen einer Poetischen Kleinform. (Beiträge zur Altertumskunde ; Bd. 130). Stuttgart: B.G. Teubner.

Formisano, M. 2016. "Displacing Tradition: A New-Allegorical Reading of Ausonius, Claudian and Rutilius Namatianus", in The poetics of Late Latin literature, edd. J Elsner and J. Hernandez Lobato, 207-35. Oxford: Oxford University Press.

Formisano, M. 2018. "Fragments, Allegory, and Anachronicity. Walter Benjamin and Claudian" in Reading Late Antiquity. The Library of the other Antiquity, edd. M. Malm and S. Cullhed, 33-50. Bibliothek der klassischen Altertumswissenschaften, 156. Heidelberg: Universitätsverlag C. Winter. Gärtner, T. 2007. "Zur Sinntendenz von Claudians mythologischer Dichtung De raptu Proserpinae” Classica et mediaevalia 58: 285-317.

Gillett, A. 2012. "Epic Panegyric and Political Communication in the Fifth-Century West" in Two Rome: Rome and Constantinople in Late Antiquity, edd. L. Grig \& G. Kelly, 265-90 (Oxford studies in late antiquity). Oxford: Oxford University Press. 
Gruzelier, C. 1993. Claudian, De Raptu Proserpinae; edited with introduction, translation, and commentary. Oxford: Clarendon Press.

Hall, J. B. 1969. Claudian, De raptu Proserpinae. Edited with an Introduction and Commentary. Cambridge: Cambridge University Press.

Harrison, S. 2017. "Metapoetics in the prefaces of Claudian's De raptu Proserpinae", in The poetics of Late Latin literature, edd. J Elsner and J. Hernández Lobato, 236-51. Oxford: Oxford University Press.

Heather, P. J. 1991. Goths and Romans 332-489. Oxford: Clarendon Press.

Heslin, P. J. 2005. The transvestite Achilles: Gender and genre in Statius' Achilleid. Cambridge: Cambridge University Press.

Hinds, S. 2013. "Claudianism in the De Raptu Proserpinae", in Generic Interfaces in Latin Literature edd. T.D. Papanghelis, S.J. Harrison, and S. Frangoulidis, 169-92. Trends in Classics Suppl. Vol. 20. Berlin: De Gruyter.

Hinds, S. 2016. "Return to Enna: Ovid and Ovidianism in Claudian's De raptu Proserpinae", in Repeat Performances: Ovidian Repetition and the Metamorphoses edd. Laurel Fulkerson and Tim Stover, 249-78. Madison: The University of Wisconsin Press.

Jiménez San Cristóbal, A. 2015. “The Rape of Persephone in a Berlin Papyrus”, Les Études classiques 83: 237-260.

Jones, Brandon F. 2019. "The Poetics of Legalism: Ovid and Claudian on the Rape of Proserpina", Arethusa 52.1: 71-104.

Liebeschuetz, J. H. W. G. 1992. 'Alaric's goths: nation or army?', in Fifth-century Gaul: a crisis of identity?, edd. J. F. Drinkwater and H. Elton, 75-83. Cambridge: Cambridge University Press.

Long, J. 1996. Claudian's In Eutropium Or, How, When, and Why to Slander a Eunuch. Chapel Hill: University of North Carolina Press.

Marrón, G. 2011. El Rapto de Prosérpina. Un nuevo contexto para la trama épica. Bahía Blanca. 
Mastrangelo, M. 2009. 'The decline of poetry in the fourth-century West', International Journal of the Classical Tradition 16: 311-29.

McEvoy, M. A. 2013. Child emperor rule in the late Roman West, AD 367-455. Oxford; New York: Oxford University Press.

Miguélez-Cavero, L. 2008. Poems in context: Greek poetry in the Egyptian Thebaid 200-600 AD Sozomena. Studies in the Recovery of Ancient Texts 2. Berlin, New York: de Gruyter. O’Hara, J. J. 2007. Inconsistency in Roman Epic: Studies in Catullus, Lucretius, Vergil, Ovid and Lucan. Cambridge: Cambridge University Press.

Öhrman, M. 2018. “Textile Work in Shared Domestic Spaces in the Roman House: The Evidence from Latin Poetry”, Fasciculi Archaeologiae Historicae 31: 93-101.

Olszaniec, S. 2013. Prosopographical studies on the court elite in the Roman Empire (4th century $A D$ ), trans. J. Wełniak and M. Stachowska-Wełniak, Toruń: Nicolaus Copernicus University Press. Parkes, R. 2005. “Model Youths? Achilles and Parthenopaeus in Claudian's Panegyrics on the Third and Fourth Consulships of Honorius”, Illinois Classical Studies 30: 67-82.

Parkes, R. 2015. "Love or War? Erotic and martial poetics in Claudian's De Raptu Proserpinae”, Classical Journal 110.4: 471-92.

Pelttari, A. 2014. The Space That Remains: The Reading of Latin Poetry in Late Antiquity. Ithaca, New York: Cornell University Press.

Pollmann, K. 2017. The Baptized Muse: Early Christian Poetry as Cultural Authority. Oxford: Oxford University Press.

Richardson, N. J. 1974. The Homeric Hymn to Demeter. Oxford: Clarendon Press.

Rosati, G. 2004. "La strategia del ragno, ovvero la rivincita di Aracne. Fortuna tardo-antica (Sidonio Apollinare, Claudiano) di un mito ovidiano", Dictynna 1 (on-line).

Shaw, Brent D. 2011. Sacred Violence: African Christians and sectarian hatred in the age of Augustine. Cambridge: Cambridge University Press. 
Schmitz, C. 2004. "Das Orpheus-Thema in Claudians De raptu Proserpinae", in Aetas Claudianea. Eine Tagung an der Freien Universität Berlin vom 28. bis 3. Juni 2002, edd. W.-W.Ehlers, F. Felgentreu and S. M. Wheeler, 38-56. Munich: K. G. Saur.

Vessey, D. 1973. Statius and the Thebaid. Cambridge: Cambridge University Press.

von Albrecht, M. 1989. “Proserpina's tapestry in Claudian's De raptu: Tradition and design", ICS 14: 383-90.

von Albrecht, M. 1997. A History of Roman Literature from Livius Andronicus to Boethius: with special regard to its influence on world literature. Mnemosyne, Supplements 165. Leiden; New York: Brill.

Ware, C. 2012. Claudian and the Roman Epic Tradition. Cambridge: Cambridge University Press. Wijnendaele, J. W. P. 2017. "The Career and 'Revolt' of Gildo, comes et magister utriusque militiae per Africam”, Latomus 75: 385-402.

Wheeler, S. 1995a. "Imago Mundi: Another View of the Creation in Ovid's Metamorphoses", AJP 116: $95-121$.

Wheeler, S. 1995b. “The Underworld Opening of Claudian's De Raptu Proserpinae”, TAPA 125: $113-34$.

Wheeler, S. 2007. "More Roman than the Romans of Rome: Virgilian (Self-)Fashioning in Claudian's Panegyric for the Consuls Olybrius and Probinus" in Texts and Culture in Late Antiquity: Inheritance, Authority, and Change, ed. J. H. D. Scourfield, 97-133. Swansea: Classical Press of Wales.

Zissos, A. 2014. "Stoic Thought and Homeric Reminiscence in Valerius Flaccus' Argonautica" in The Philosophizing Muse: The Influence of Greek Philosophy on Roman Poetry, edd. by M. Garani, D. Konstan, 269-97. Newcastle upon Tyne: Cambridge Scholars Publishing.

\footnotetext{
${ }^{\mathrm{i}}$ Mastrangelo (2009), 325.

ii See e.g. Hinds (2013), 169-92.
} 
${ }^{\text {iii }}$ A last possible end date of C. E. 404 is usually accepted since no more is heard of Claudian after this. Aside from this, there is considerable critical disagreement over when the $D R P$ may have been composed. So e.g. Hall (1969: 93-105) argues the poem was begun before C. E. 395 and resumed later under the auspices of Florentinus whom he assumes to be the Florentinus who was in charge of the prefecture of Rome from 395 until he was replaced at the beginning of 398 (for this man, see Olszaniec 2013: 195-204). Hall does not see a necessary link with the period when Florentinus was prefect: as Hall (1969: 105, n. 2) notes, there seems to be evidence of Florentinus in a letter of Symmachus which may be dated to C. E. 402. For views, see Felgentreu (1999), 157-60; Marrón (2011), 43-63, who herself suggests Florentine (pr. 2.50) indicates Manlius Theodorus (2011: 5663) and posits composition in C. E. 396-7 and the first public performance of the poem in C. E. 398 (2011: 63). Charlet (1991: xx-xxxi) tentatively argues for composition of Book 1 before C. E. 395 but for support for the idea that the DRP was composed after the Prob. et Olybr., cf. c.m. 41.13-14 with Wheeler (2007), 98. This article assumes a composition period which spanned, at the least, some years. Even if the DRP was started immediately after the Prob. et Olybr., it seems likely that that the three books were written, and separately circulated, over several years: see below for the reference to a compositional gap at pr. 2.51. Quotations of the DRP are taken from Hall (1969); translations are my own.

iv See Cameron (1970); Gillett (2012).

${ }^{v}$ Cf. von Albrecht (1997), 1337, n. 3. Stilicho seems to have been the main patron for whom Claudian's poems provided sequenced commentary (Gillett 2012: 282-3).

${ }^{\text {vi }}$ Cf. Shaw (2011), 47, n.113: 'Between Julian in 360 and Gratian in 383, no emperor in the West held power for more than eleven years, many for less than this'.

vii See McEvoy (2013), 153-62 for historical background.

viii On Stilicho's claim to guardianship over Arcadius, see McEvoy (2013), 142-3. As Ware (2013: 70) notes, the East rejected this claim of regency. 
${ }^{\text {ix }}$ For the spinning of Theodosius' deathbed speech, see Parkes (2005), 81; McEvoy (2013), 142-3.

${ }^{\mathrm{x}}$ For the revolt, see Heather (1991), 193-5; 201-4. By C. E. 404 an alliance with Stilicho was on the cards: see Liebeschuetz (1992), 80.

${ }^{x i}$ Cf. Pollmann (2017), 47.

xii See Pollmann (2017), 51.

xiii See e.g. Long (1996), 38 for its invective form.

${ }^{\text {xiv }}$ See Kelly (2012), 253, noting that, although the second book was probably not planned when the first was finished, it was written in a way which engaged with the first.

${ }^{x v}$ For this coverage, see Kelly (2012), 244.

${ }^{x v i}$ Cf. Long (1996), 50: "only book 2 lives up to epic standards in scope and treatment".

${ }^{\text {xvii }}$ Cf. Wheeler (2007) at 119 on the ancestress Faltonia Betitia Proba (on whom see further Cameron 2011: 327-37). Wheeler (2007: 117-18) also suggests Claudian may have been appealing to the Christian faith of the Anicii by leaving open an allegorical reading through evocation of Vergil Eclogue 4.

xviii Cf. Wheeler (2007), 99, 117.

xix On the ending see Hinds (2013), 190-1.

${ }^{\mathrm{xx}}$ See Heslin (2005), 66-9. We might argue that Claudian is placing his work in the long tradition of unfinished Latin epics such as Statius' Achilleid (which Heslin sees as a structural model). ${ }^{x x i}$ It seems likely that Florentine (pr. 2.50) refers to the Florentinus who became prefect of Rome rather than Manlius Theodorus (Marrón, as above) or Stilicho (see Cameron 1970: 453-4, arguing against Widekind's suggestion this was a nickname attributed to Stilicho after the battle of Faesulae, near Florence, in 406). It may be less likely Florentinus should be apostrophized in this way after his fall from power (Harrison 2017: 246) but, if the poem was circulated in its extant form after Florentinus' fall, this would have increased the sense of provisionality.

xxii On Orpheus as a poet-figure for Claudian, see von Albrecht (1989), 388; Schmitz (2004), 49, n. 26; Bureau (2009), 55-63; Harrison (2017), 247. 
xxiii See Hinds (2016), 254.

${ }^{\text {xxiv }}$ Hinds (2016), 273, n. 20 notes the preface's links to Vergil G. 4.454-527.

${ }^{x x v}$ Cf. Hinds (2016), 273, n. 20, with acknowledgment of the detection of the parallels between Met. 11.2 and DRP 2 pr. 49 to Stover, per litteras. DRP pr. 2.7-8 recalls the mourning of rocks and trees for Orpheus at Ov. Met. 11.45-6 (Felgentreu 1999: 173-4) and also the demonstration of his ability to draw trees and rocks at Met. 11.1-2. The three trees mentioned by Claudian, the poplar (2 pr. 21), pine (2 pr. 22), and laurel (2 pr. 24), appear in Ovid's catalogue of listening trees: cf. Met. $10.91 ; 10.92 ; 10.104$ (pine). Moreover, two of these trees are depicted in ways that recall Ovid's description: Claudian's attribution of the epithet amica to the pine (DRP 2 pr. 22) recalls Attis' relationship with Cybele (Met. 10.104-5). The reference to the laurel's scorning of Apollo's arts (2 pr. 23) resonates with Ovid's evocation of Daphne's repudiation of Apollo and preservation of her virginity (Met. 10.92).

${ }^{x x v i}$ For the prefiguration of the unfinished ending in the interruption of Proserpina's weaving, see Formisano (2016), 225.

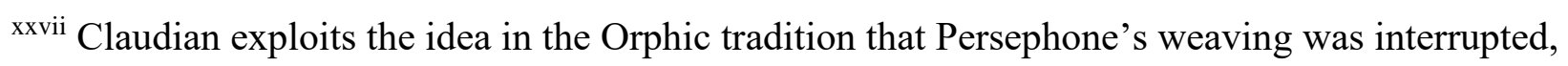
whether through her abduction by Hades or her seduction by Zeus (OF 228, 286, 288). It is only some twenty lines after this reference to the unfinished tapestry that we come to the end of the first book and the beginning of the second which conjures the possibility of its own non-existence. xxviii Observed by Wheeler (1995a) at 111, n.56. For Proserpina as a figure for the poet, see e.g. Pelttari (2014), 162.

${ }^{\text {xxix }}$ Other effects of disruption, such as the "half-demolished warp with its disordered threads" (DRP 3.155 semirutas confuso stamine telas), can be attributed to tremors arising from the tunnelling Dis' disturbance of Enceladus (2.152-3; 2.158-61) and his striking of rocks (2.173). The idea of ruin arising from a long delay (cf. Gruzelier 1993 on 3.146ff. and 3.154ff.; Rosati 2004, section 80; Hinds 2016, 274, n. 25) is overplayed by critics. 
xxx Gruzelier (1993) ad loc.

xxxi One wonders how Proserpina felt about the "pleasure" (DRP 3.205 gratia) of conversation with the aged nurse.

xxxii Identified as weaving by Öhrman (2018), 98.

xxxiii This lays "emphasis on the action rather than the agent" (Gruzelier 1993 ad loc.); cf. the impersonal construction at $D R P 2.237$.

${ }^{\text {xxxiv }}$ Cf. DRP 3.245 inuenimus; 3.248 adgredimur; scitamur. The use of the third person pronoun nobis $(3.201)$ and forms of noster $(3.199 ; 3.215)$ associates herself with the side of the injured party. The return to first personal singular at 3.259 (relinquor), emphasised by sola, brings out Electra's special commitment.

${ }^{x x x v}$ The co-existence of third and first person accounts of the abduction goes back to HHD 1-31 and 406-33.

xxxvi There may be particular cause for anxiety given punishment for slaves under late antique raptus law: see Jones (2019), 97, who makes a connection between Electra's inconsistency and contemporary legislation.

${ }^{x x x v i i}$ On inconsistency in the Lycaon episode of Ovid Metamorphoses 1.163-252, see O'Hara (2007), 116-17; Balsley (2011), 62-3.

xxxviii See, e.g., the way that Jupiter acknowledges his destruction of the household at Ov. Met. 1.230-1 with “avenging thunderbolt" (1.230 vindice flamma) but Lycaon's transformation is related impersonally at 1.232-9, creating the sense that it is not just Jupiter who is involved: "Notice that Jupiter never claims responsibility for the transformation, which appears to happen spontaneously, as if nature were simply taking its course" (Feldherr 2002: 170).

xxxix See O'Hara (2007), 117.

${ }^{x l}$ See Feeney (1991), 346-52 on the upper/underworld power struggle in the Thebaid.

xli The relationship of Fate and Jupiter in the Thebaid is a complex issue: see e.g. Dominik (2004), 25-9. So, for instance, there is the suggestion that fate follows Jupiter's words at Theb. 1.213. A 
Stoic identification of Jupiter's will with Fate is suggested at Theb. 3.242-3: cf. the model passage of V. Fl. 1.531-3 with Zissos (2014), 281. However, as in the depiction of Valerius Flaccus' Jupiter (Zissos 2014: 242), there are "moments of slippage in which a more personal deity lurks behind the Stoic language" (pace Vessey 1973: 82).

${ }^{\text {xlii }}$ Cf. DRP 2.282-93. For a politicized reading of Claudian's ameliorated version of Hades, see Hinds (2013), at 177 and Hinds (2016), 263.

xliii The way the sky is focalized as from the point of view of Dis' horses as "better" (meliore) at DRP 2.195 also encourages us to view Dis' words as carefully constructed rhetoric.

${ }^{x l i v}$ For the sun and stars in Elysium, see e.g. Verg. A. 6.640-1.

xlv See e.g. Gärtner (2007), 298-9.

${ }^{\text {xlvi }}$ So Gruzelier (1993) ad DRP 1.218f.

xlvii Cf. the situation in Statius' Thebaid above, a possible model.

xlviii DRP 3.65 mansura fluant hoc ordine fata, "let the fates/words, which will be in store, flow on in this course”. Cf. Gild. 201-3 where Atropos writes down Jupiter's words and Lachesis joins threads and words.

${ }^{\text {xlix }}$ See also DRP 1.224-8 where Jupiter appeals to Venus' lust for dominion, using similar tactics to those deployed by the Ovidian Venus to coax Cupid into aiding her (Ov. Met. 5.365-79; Wheeler 1995b: 121).

${ }^{1}$ See De Raptu 3.82-90 with Parkes (2015), 483.

li Cosgrove (2004), 5.

lii DRP 2.162. Cf. 1.155-9 (Enceladus defeated in the giants-gods fight); 3.350 (the giant's spoils still smoking from Jupiter's thunderbolt). See Fauth (1988), 69-70.

liii Zeus' thunderbolt was an Orphic tradition (see Jiménez San Cristóbal 2015: 248) but Claudian adapts this to suggest the theme of gigantomachy.

${ }^{\text {liv }}$ Cf. Eur. Ion. 987-97 (Athene as gorgon-slayer in the gigantomachy and thence wearer of the gorgon's skin as aegis); Claud. c.m. 53.92.

${ }^{\text {Iv }}$ Cf. DRP 3.314. See Wheeler (1995b), 129 (for the switch in mapping); 130-1. 
${ }^{\text {lvi }}$ See Parkes (2015), 482 for the clash of perspectives over whether it is a forced abduction or an agreed marriage.

lvii The tension is captured by the close proximity of raptu and dotale at DRP 1.27-8.

${ }^{1 v i i i}$ For consent, see Parkes (2015), 482, n. 67. See Jones (2019), 88-97 for abductive marriage and attempts to clamp down upon it, with reference to the $D R P$.

${ }^{\text {lix }}$ Parkes (2015), 483. The fact that Proserpina appears in a vision adds to the interpretative uncertainty.

Ix See Wheeler (2007), 119.

${ }^{1 x i}$ For Florentinus as a bestower of peace, see DRP pr. 2.10 "with his peace-bringing foot" (pacifero ... pede). Schmitz (2004: 53) sees links with the "peace-bringing wings" (DRP 2.229 pacificas ... alas) of Jupiter's thunderbolt designed to preserve the order of the world. The extent to which the content of books 2 and 3 responds to the character and deeds of Florentinus is hard to evaluate in light of the uncertainty over his identity and the poem's composition: for instance, the identification of Florentinus as city prefect facing supply shortages during the grain crisis, by a contemporary or later reader, would open up connections with Claudian's treatment of agricultural subject matter (DRP 1.30 unde ... fruges, “whence grain...”): cf. e.g. Birt (1892), xvi-xvii. Nevertheless, we cannot overlook the resonance of the appellation Florentinus (cf. floreo, "I bloom") with the special emphasis on flowers and flowering in Books 2 and 3 of the narrative: as well as references to the flowers of Sicily (DRP 2.101; 2.140; $2.265 ; 3.220 ; 3.439)$ and the underworld $(2.289)$, note the way the house and Proserpina are said to be "flourishing" at 3.202 and 3.417. The verb floreo appears only twice in the first book: of Iacchus at $D R P 1.17$ and in the context of Ceres' promise of future fertility to Sicily at 1.199 .

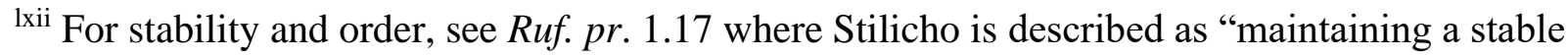
world for the brother Emperors" (stabilem seruans Augustis fratribus orbem); Coombe (2018), 123. For concord, see e.g. Ware (2012), 123-8 on Stilicho's association with concordia in the In Rufinum and his opposition to Rufinus, a personification of discordia. 
${ }^{1 x i i i}$ For the impression Stilicho was involved in Rufinus' death, see Ruf. 2.402-3 with Ware (2012), 45. For the hand of providence, see e.g. Ruf. 1.20-23; Ware (2012), 128.

lxiv See Gillett (2012), 283, n.64 for Claudian's evocation of prior works and material.

${ }^{1 x v}$ Claudian would have experienced suitable declamatory experience (see Miguélez-Cavero (2008),

39 for examples of epithalamia from the Egyptian Thebaid which could act as comparative material). The exact relationship between the composition of the epithalamic poetry for Honorius' wedding (C. E. 398) and the composition of the De Raptu must remain uncertain. However, if the epithalamic poetry had not yet been composed, one can still argue for the De Raptu as a response to the issues of dynastic coupling and succession which must have been in the air. 